\title{
Detection of respiratory viral antigens in cattle lung tissues by direct ELISA
}

\author{
Oguzhan Avci', *, Sibel Yavru', Mehmet Ekik ${ }^{2}$ \\ ${ }^{1}$ Department of Virology, Faculty of Veterinary Medicine, University of Selcuk, 42075, Konya, Turkey \\ ${ }^{2}$ Virology Laboratory, Veterinary Control Institute, 42080, Konya, Turkey

\section{Email address:} \\ oavci@selcuk.edu.tr (O.Avci), sibelyavru@selcuk.edu.tr(S. Yavru), mehmetekik@hotmail.com (M. Ekik)
}

\section{To cite this article:}

Oguzhan Avci, Sibel Yavru, Mehmet Ekik. Detection of Respiratory Viral Antigens in Cattle Lung Tissues by Direct ELISA. Animal and Veterinary Sciences. Vol. 2, No. 5, 2014, pp. 146-149. doi: 10.11648/j.avs.20140205.13

\begin{abstract}
Bovine Respiratory Disease is one of the most important diseases with serious financial losses for the cattle industry in worldwide. The aim of this study was to detect the associations between respiratory viruses; bovine herpes virus 1 , bovine viral diarrhea virus, bovine respiratory syncytial virus, and Para influenza virus 3 statuses of a herd and bovine respiratory disease occurrence. Present study describes virological distribution of bovine respiratory viruses in nonvaccinated cattle (for mentioned infections) of Central Anatolia, Turkey. A total of 24 lung tissue samples were collected during the December 2012 to January 2013 from cattle that died after manifesting clinical signs of respiratory system. Samples were successfully homogenized. Tissue samples were analyzed for detecting antigens by commercially available direct ELISA kit. BRSV antigens were detected in lung tissues 4 out of 24 tested cattle with a percentage of $16.6 \%$, whereas BHV-1, BVDV and PI-3 were not found. BRSV may be common reason of respiratory diseases in herds. It has been also offered advice about prevention of respiratory viral infection for health planning. In conclusion, existence of BRSV infection is still defined and may play an important role in the respiratoric viral infection of cattle.
\end{abstract}

Keywords: BHV-1, BRSV, BVDV, PI-3, ELISA

\section{Introduction}

Bovine Respiratory Disease (BRD) infection occurs in cattle in different regions of the world [1,2]. Respiratory viruses such as bovine herpes virus 1 (BHV-1), bovine viral diarrhea virus (BVDV), bovine respiratory syncytial virus (BRSV), and Para influenza virus 3 (PI-3) are the most important disease for cattle industry in worldwide [3].

BHV-1 is a pathogen of cattle associated with two major syndromes, called infectious bovine rhinotracheitis (IBR) and infectious pustular vulvovaginitis (IPV), it is characterized by abortion, encephalitis fatal disease in newborn calves, mastitis, tracheitis, and thus causes great economic losses to the young and adult cattle industry $[4,5]$. It is a member of the family Herpesviridae, subfamily Alphaherpesvirinae [6].

BVDV causes a disease in cattle, and characterized with respiratory and reproductive symptoms, abortions, mummification, congenital anomalies, still-births, and birth of persistently infected (PI) carrier animals, and can lead to fatal mucosal disease $[7,8]$. BVDV is a Pestivirus in the
Flaviviridae family and is closely related to Classical Swine Fever and Border Disease Virus [9]. BVDV strains are divided into two biotypes such as noncytopathic (ncp) and cytopathic (cp) according to proliferation in cell culture [10].

BRSV infection is characterized with rhinitis, coughing, abdominal breathing, bronchiolitis, reduced appetite, interstitial edema, emphysema and some cases progressing to sever bronchopneumonia may end with death [11]. It is a member of the family Paramyxoviridae, genus Pneumovirus. BRSV genome is negative sense, single stranded, non-segmented RNA, and $15.2 \mathrm{~kb}$ long [12]. Serological tests such as Enzyme Linked Immunosorbent Assay (ELISA), Complement Fixation Test (CFT), and Serum Neutralization Test (SNT) are useful for BRSV diagnosis [13].

PI-3 is a member of the family Paramyxoviridae, subfamily Paramyxovirus. PI-3 is an enveloped, nonsegmented, negative-sense RNA virus. It is characterized with acute and silently fever, rhinitis, nasal secretions [14]. PIV-3 causes generally subclinical infections and clinical symptoms but with secondary bacterial and other viral infections may lead death [15]. 
Diagnosis of major viral causes of bovine respiratory infections has been based largely on the serological testing by Virus Neutralization Test (VNT), ELISA, Immunofluorescence Antibody (IFA), Hem-agglutination Inhibition (HI), and nested Polymerase chain reaction [16]. Detecting and controlling bovine viral respiratory diseases can decrease economic losses [17].

The present study was planned to detect the associations between respiratory viruses; BHV-1, BVDV, BRSV, and PI3 status of a herd and BRD occurrence using ELISA.

\section{Materials and Methods}

A total of 24 lung tissue samples were collected during the December 2012 to January 2013 from dead cattle (2-3 years) for the presence of respiratory viral antigens in a dairy cattle herd (250 capacity) in Konya, Central Anatolia region of Turkey. Individual samples of lung tissues (approximately 1 gram) were collected max 6 hours after dead during necropsy by Veterinary and successfully homogenized with $2 \mathrm{ml}$ of lysis solution and centrifuged at $500 \mathrm{rpm}$ for $10 \mathrm{~min}$ to obtain the supernatant. All applications were performed under sterile conditions. Tissue samples were analyzed for detecting mentioned viral antigens by a commercially available direct ELISA kit (Biox Diagnostics, BIO K 340/2, Belgium) in Virology laboratories of Veterinary Medicine Faculty of Selcuk University. The test was performed as per the manufacturer's instructions. The plates were then read on an automatic micro plate reader (Rayto RT 2100C, China) at $450 \mathrm{~nm}$. ELISA results were calculated for each sample the $\mathrm{S} / \mathrm{P}$ ratio (in \%):

$$
\frac{\mathrm{S}}{\mathrm{P}(\%)}=\frac{\mathrm{OD}_{\text {sample }} * 100}{\mathrm{OD}_{\text {Positive Control }}}
$$

Samples were considered positive for an S/P $(\%)>6.94$ for BHV-1, > 7.50 for BVDV, > 6.99 for BRSV, and > 6.93 for PI-3. Statistical significance of differences between viral infections was analyzed using Chi-square analysis (Minitab 14.0 Inc., State College, PA, USA). P $<0.05$ level was accepted statistically significant.

\section{Results}

Table 1. Direct ELISA results of lung tissue

\begin{tabular}{ll}
\hline Infection & ELISA-Ag \\
\hline BHV-1 & $0 / 24^{\mathrm{b}}$ (Not detected) \\
BVDV & $0 / 24^{\mathrm{b}}$ (Not detected) \\
PI-3 & $0 / 24^{\mathrm{b}}$ (Not detected) \\
BRSV & $4 / 24^{\mathrm{a}}(16.6 \%)$ \\
\hline
\end{tabular}

a, b, Values marked with different letters in the same column are statistically significant $(\mathrm{P}<0.05)$.

Specific BRSV antigens were detected in 4 out of the 24 $(16.6 \%)$ tested cattle lung samples (Table 1). No positive sample was obtained for other viruses (BHV-1, BVDV and PI-3).

\section{Discussion}

Bovine respiratory diseases are the most important diseases affecting respiratory tract both young and adult cattle in worldwide [18]. The primary viral respiratory pathogens are BHV-1, BRSV, and PI-3 in cattle [19]. In this study, a total of 24 lung tissue samples were collected from died cattle after manifesting clinical signs of respiratory system in Central Anatolia. Specific BRSV antigen was detected in 4 lung tissue sample out of 24 tested samples with a percentage of $16.6 \%$ and there were no positive samples for other infections.

The serologic and virologic evidence of infections caused by respiratory viruses in Turkey has been demonstrated different studies previously [20,21]. The serologic evidence of BRSV infections in Turkey [20,21] and other countries [22,23] has been demonstrated different studies previously. It is known that lung tissue samples containing high amount of BRSV antigens [24]. Also, most cases of BRSV infections occurring in late autumn and winter [25]. The reason of only BRSV antigens detected in this study can be explained by sampled season and tissues.

It is reported that virus isolation and fluorescent antibody test (FAT) are more sensitive and simple for antigen detection than ELISA in the diagnosis of BRSV infection [26]. However, the ability to perform ELISA within a short time frame to detect different viral agents reduces hands-on time in the laboratory, is more efficient in differential diagnosis [27]. In this study, the samples have no examined by FAT or isolation so there is not evaluated the specificity of other tests. But detection of BRSV antigen by direct ELISA, it can be played an important role of cattle dead.

In consideration of the characteristic of herpesvirus infections to establish latency, it couldn't detect in lung samples [28]. In the current study, all lung samples were detected as negative for PI-3. So it has not been evaluated the reason of death. It has been reported that causes generally subclinical infections and clinical symptoms but with secondary bacterial and other viral infections may lead death [15].

BHV-1, BVDV, BRSV and PI-3 infections in cattle have been reported by different researchers using serologically methods $[20,29,30]$. The current study would suggest that cattle may dead when exposed to BRSV. Infection with BHV-1, BRSV and PI-3 can also facilitate invasion of secondary pathogens such as Pasteurella multocida, Haemophilus somni, Mycoplasma bovis and Mycoplasma dispar [31]. Herd capacity [21], herd management strategies and environmental conditions are highly related to BRDV infections [32]. In this study, samples were not investigated for other potential bacterial agents so it has not been considered for mix infections.

\section{Conclusion}

In conclusion, the results showed the presence of BRSV infection among cattle in Central Anatolia of Turkey. For 
control of the BRSV and other respiratory diseases, serological and virological examination should be done and prevention measures must be taken.

\section{Competing Interests}

The authors declare that they have no competing interests.

\section{Acknowledgement}

This study abstract was published in the $31^{\text {th }}$ Word Veterinary Congress, Czech Republic, 2013.

\section{References}

[1] Gillette K.G. and Smith, P.C. (1985). Respiratory syncytial virus infection in transported calves. American Journal of Veterinary Research, 46: 2596-2600.

[2] Muylkens, B., Thiry, J., Kirten, P., Schynts, F. and Thiry, E. (2007). Bovine herpesvirus 1 infection and infectious bovine rhinotracheitis. Veterinary Research, 38: 181-209.

[3] Kampa, J., Stahl, K., Moreno-Lopez, J., Chanlun, A., Aiumlamai, S. and Alenius, S. (2004). BVDV and BHV-1 infections in dairy herds in Northern and Northeastern Thailand. Acta Veterinaria Scandinavica, 45: 181-192.

[4] Tikoo, S.K., Campos, M. and Babiuk, L.A. (1995). Bovine herpesvirus 1 (BHV-1): biology, pathogenesis, and control. Advances in Virus Research, 45: 191-223.

[5] Bowland, S.L. and Shewen, P.E. (2000). Bovine respiratory disease: commercial vaccines currently available in Canada. The Canadian Veterinary Journal, 41: 33-48.

[6] Schwyzer, M. and Ackermann, M. (1996). Molecular virology of ruminant herpesviruses. Veterinary Microbiology, 53: 17-29.

[7] Peterhans, E. and Schweizer, M. (2010). Pestiviruses: How to outmaneuver your hosts. Veterinary Microbiology, 142: $18-25$.

[8] Bedekovic, T., Lemo, N., Barbic, L., Cvetnic, Z., Lojkic, I., Benic, M., Cac, Z., Lojkic, M. and Madic, J. (2013). Influence of category, herd size, grazing and management on epidemiology of bovine viral diarrhoea in dairy herds. Acta Veterinaria Brno, 82: 125-130.

[9] Safarpoor Dehkordi, F. (2011). Prevalence study of Bovine viral diarrhea virus by evaluation of antigen capture ELISA and RT-PCR assay in bovine, ovine, caprine, buffalo and camel aborted fetuses in Iran. AMB Express, 1: 32.

[10] Nettleton, P.F. and Entrican, G. (1995). Ruminant pestiviruses. The British Veterinary Journal, 151: 615-642.

[11] Ellis, J., West, K., Knobby, C., Leard, T., Gallo, G., Colon, J. and Fitzgerald, N. (2001). Efficacy of an inactivated respiratory syncytial virus vaccine in calves. Journal of the American Veterinary Medical Association, 218: 1973-1980.

[12] Mink, M.A., Stec, D.S. and Collins, P.L. (1991). Nucleotide sequences of the 3' leader and $5^{\prime}$ trailer regions of human respiratory syncytial virus genomic RNA. Virology, 185: 615-624.

[13] Masot, A.J., Gomez, T.C., Tovar, I., Gazquez, A. and Redondo, E. (1993). Location of bovine respiratory syncytial virus antigens in the lung of experimentally infected lambs: comparative study using indirect fluorescent antibody test, avidine biotin peroxidase complex and transmission electron microscopy. European Journal of Histochemistry, 37: 75-82.

[14] Solis-Calderon, J.J., Segura-Correa, V.M., Segura-Correa, J.C. and Alvarado-Islas, A. (2003). Seroprevalence of and risk factors for infectious bovine rhinotracheitis in beef cattle herds of Yucatan, Mexico. Preventive Veterinary Medicine, 57: 199-208.

[15] Banerji, A., Bell, A., Mills, E.L., McDonald, J., Subbarao, K., Stark, G., Eynon, N. and Loo, V.G. (2001). Lower respiratory tract infections in Inuit infants on Baffin Island. Canadian Medical Association Journal, 164: 1847-1850.

[16] Valentova, V., Kovarcik, K. and Psikal, I. (2003). Detection of Bovine respiratory syncytial virus in cell cultures by nRTPCR and use of the method for virus identification in clinical samples. Acta Veterinaria Brno, 72: 115.

[17] Sakhaee, E.A., Khalili, M. and Kazeminia, S. (2009). Serological study of bovine viral respiratory diseases in dairy cattle of Kerman (Iran). The Iranian Journal of Veterinary Research, 10: 49-53.

[18] Houe, H. (2003). Economic impact of BVDV infection in dairies. Biologicals, 31: 137-143.

[19] Pardon, B., De Bleecker, K., Dewulf, J., Callens, J., Boyen, F., Catry, B. and Deprez, P. (2011). Prevalence of respiratory pathogens in diseased, non-vaccinated, routinely medicated veal calves. Veterinary Record, 169: 278.

[20] Alkan, F., Ozkul, A., Bilge-Dagalp, S., Yesilbag, K., Oguzoglu, C., Akca, Y. and Burgu, I. (2000). Virological and serological studies on the role of PI-3 virus, BRSV, BVDV and BHV- 1 on respiratory infections of cattle. I. The detection of etiological agents by direct immunofluorescence technique. Deutsche Tierarztliche Wochenschrift, 107: 193-195.

[21] Yesilbag, K. and Gungor, B. (2008). Seroprevalence of bovine respiratory viruses in North-Western Turkey. Tropical Animal Health and Production, 40: 55-60.

[22] Saber, M.S., Salem, A.A., Mohamed, S.A.H., Hadia, A.H.H., Nawal, A.M., Mossa, A.A. and Fatheia, M.M. (1996). Isolation, identification and seroconversion studies on BRSV in Egypt. Veterinary Medical Journal Giza, 44: 735747.

[23] Urban-Chmiel, R., Wernicki, A., Grooms, D.L., Barbu, N. I., Rola, J. and Socha, W. (2013). Rapid detection of Bovine respiratory syncytial virus in Poland using a human patientside diagnostic assay. Transboundary and Emerging Diseases, doi: 10.1111/tbed.12134

[24] Baker, J.C., Werdin, R.E., Ames, T.R., Markham, R.J.F. and Larson, V.L. (1986). Study on the etiologic role of bovine respiratory syncytial virus in pneumonia of dairy calves. Journal of the American Veterinary Medical Association, 189: 66-86. 
[25] Van der Poel, W.H., Brand, A., Kramps, J.A. and Van Oirshot, J.T. (1994). Respiratory syncytial virus infections in human beings and in cattle. Journal of Infection, 29: 215228 .

[26] Lokensgard, B.E., Goyal, S.M. and Krueger, D.A. (1992). Comparison of three immunoassays for the rapid detection of bovine respiratory syncytial virus. Microbiologica, 15: 259-264.

[27] Thonur, L., Maley, M., Gilray, J., Crook, T., Laming, E., Turnbull, D., Nath, M. and Willoughby, K. (2012). One-step multiplex real time RT-PCR for the detection of bovine respiratory syncytial virus, bovine herpesvirus 1 and bovine parainfluenza virus 3. BMC Veterinary Research, 8: 37.

[28] Sausker, E.A. and Dyer, N.W. (2002). Seroprevalence of OHV-2, BVDV, BHV-1, and BRSV in ranch-raised bison (Bison bison). Journal of Veterinary Diagnostic Investigation, 14: 68-70.
[29] Yavru, S., Simsek, A., Yapkic, O. and Kale, M. (2005). Serological evaluation of viral infections in bovine respiratory tract. Acta Veterinaria (Beograd), 55: 219-226.

[30] Duman, R., Yavru, S., Kale, M., and Avci, O. (2009). Seroprevalence of viral upper respiratory infections in dairy cattle. Journal of the Faculty of Veterinary Medicine, University of Kafkas, 15: 539-542.

[31] Hodgson, P.D., Aich, A., Manuja, A., Hokamp, H., Roche, F.M., Brinkman, F.S.I., Potter, A., Babiuk, L.A., and Griebel, P.J. (2005). Effect of stress on viral-bacterial synergy in bovine respiratory disease; novel mechanisms to regulate inflammation. Comparative and Functional Genomics, 6: 244-250.

[32] Valarcher, J.F. and Haaglund, S. (2006). Viral respiratory infections in cattle. In: Proceedings of XXIV World Buiatrics Congress, Nice, France, 2006. 